\title{
Consistency Analysis of Port Industry Development and Chinese Economic Development
}

\author{
Jianping Sun,Zhenfu Li,Yunxiao Guan,Tongchao Liu \\ College of shipping economics and management,Dalian Maritime University, Dalian 116026, China
}

\begin{abstract}
As a function in organization and management, coordination is used to adjust the interrelation of the individuals in the organization in order to achieve the ultimate goal. Coordination can make individuals groups in a whole, reduce the contradiction and conflict between each other and promote the realization of the overall goal. The research on the coordination of relationship between the port industry of China and the growth of economy plays an important guiding role for the port industry and healthy development of national economy. According to the correlation model between port industry and economic growth, the correlation factor between port industry and economic growth is extracted, and the coordination indicator system of the relationship between the port industry and economic growth is established. Then, this article makes correlation analysis of the standardization of indicators, removes the bigger indicators of correlation coefficient and eliminates the impact of the duplication of information between indicators in order to simplify the indicator evaluation system. The actual results by data calculation show that there were six obvious changes in the coordination degree of the relationship between the port industry and economic growth in China during the period from 1990 to 2014.
\end{abstract}

\section{Introduction}

Coordination in the organization and management is a function to achieve the ultimate goal by regulating the relationship between the individual organizations, it can make these individuals in a whole, to reduce the contradiction between each other, to promote the realization of the overall goal ${ }^{[1]}$. The study of the coordination relationship between port industry and economic growth plays an important role in guiding the healthy development of port industry and national economy. In order to effectively measure the relationship between the two, this paper introduces the coordination index to assess the relationship between port industry and economic growth in China. In view of the lack of research on the relationship between port industry and economic growth, and taking into account the important role of the coordination relationship between port industry and economic growth on the development of national economy, this paper focuses on the coordination degree of the relationship between the two industries. Through the investigation of the correlation pattern between the two, the coordination degree evaluation model is established, and the coordination level of the two is quantitatively analyzed to explore the coordination degree between the port industry development and economic growth in China, and then guide the healthy development of China's port industry.

\section{A Study on the Relevance Model of Port Industry and Economic Growth}

As a demand industry which is derived from the process of national economic development, the port industry plays an important role in the development of national economy. It combines the production, distribution, exchange and consumption of domestic and foreign trade and economic activities organically. It plays an important pillar role in the development of the national economy. At the same time, shipping as a carrier of import and export trade, for the import and export trade in the world to provide the possibility of the port as an important interface to maritime transport development has a great role in promoting. Therefore, it is clear that the correlation between port industry and economic growth contributes to the further innovation of the port industry and can also serve as an important basis for the development of national development strategies.

\subsection{Contribution of Port Industry to Economic Growth}

The first one is the impact of a region's economy. Combined with the development of domestic and international port industry, can be found in the development of the port industry has a strong effect of aggregation, according to Hong Kong City, Hong Kong and cities linked to the economic development model more common. Port as the core of the development of the city, because it has close to the transport node, low transport costs, the advantages of a single volume, often become the best area to attract the relevant industries gathered to form a port industrial clusters, these industrial clusters Attracting talent, technology and other elements of a large number of inflows, the formation of a strong competitive industrial clusters, and thus promote the 
development of the city, its direct performance is the region's GDP growth. And as a comprehensive reflection of the regional economic development indicators, GDP can clearly show the role of port industry in promoting economic growth. The second one is the promotion of labor and employment role [2]. Expressed ad the performance of the port industry in promoting the employment, each additional unit of output value can directly use or mobilize the number of labor personnel situation in relevant industry. When the port industry participates in economic activities, it has a great correlation with other industries. The port industry, as a derivative industry, provides services such as loading and nloading and transit for the economic activities of other sectors. At the same time, the port industry needs to develop manufacturing, trade and other industries to provide services and products, and in the process of labor and employment generated by the relevant areas to meet the needs of the employment of workers in the region to promote the employment of workers in order to create more social production value and promote economic growth.

\subsection{The Effect of Economic Growth on the Development of Port Industry}

One is to provide direct financial support for the development and construction of the port industry. In the course of economic development in a country or region, the accumulation of capital can provide financial support for the development of the national economic sector. As the economy continues to grow, the region's capital stock will increase, in order to promote the port industry and related industries to upgrade the allocation of resources for the port industry to provide a strong scale of protection. When the infrastructure construction of the port industry reaches a certain level, it can speed up the development of the port industry and enhance the service level of the port industry, so as to better serve the economic construction. Similarly, when the development of the financial system of an area's port industry is relatively complete, it can attract relevant industries such as industry, trade and logistics, and bring together the resources, talents, technology and other resources in the region to form a whole industrial chain, so as to enhance the quality of the development of the port industry in the region, the region's port industry to increase the core competitiveness.

The other one is to provide indirect trade logistics needs for the development of the port industry. The purpose of the port industry is to meet the logistics needs, so as to promote economic and social development. Economic growth, as the driving force behind the demand for logistics, can provide constant demand for the development of the port industry. When a region's economy continues to grow, it will stimulate the continuous development of various industrial sectors, resulting in a huge trade logistics needs, and shipping with large volume, low cost, low energy consumption advantages, in terms of foreign trade, Country or region of the main transport tasks. Port as a hub for maritime transport, in the realization of maritime missions play an important role, therefore, by the economic growth caused by the demand for trade logistics will be completed by means of the port industry, which indirectly contributed to the development of the port industry.

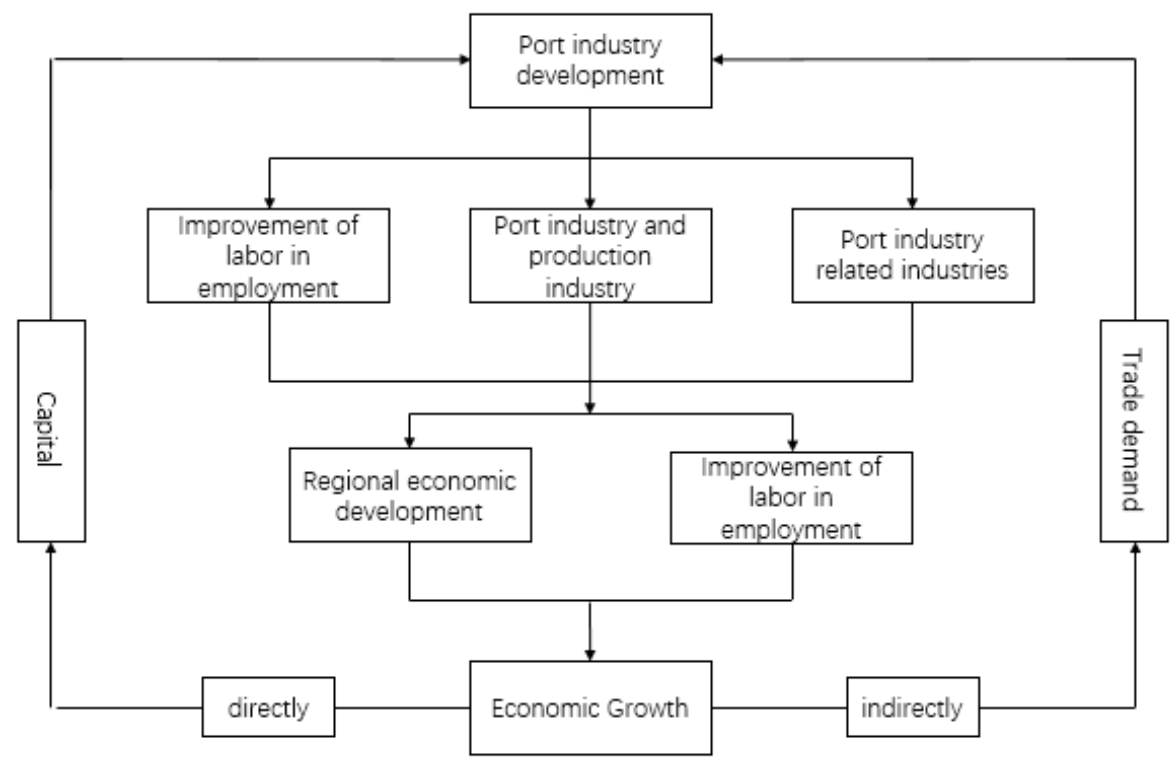

Fig 1. The correlation model between port industry and economic growth 


\section{Coordination Model of Port Industry and Economic Growth}

The purpose of coordination is "harmony and consistency, with appropriate" [3]. From the system point of view, coordination refers to the system or between the various levels of the system, the various parameters of the system between the harmony, with the appropriate, structure and function of the relationship between the integration of coordination through the system can reduce the negative Effect, and improve the overall output function and synergistic effect of the system. The coordination degree of a system can be expressed as the degree of harmony between the elements of the system or the system, which can reflect the trend and degree of the system from disorderly to orderly development, and can effectively measure the internal factors of the system or system The level of coordination between the level. Thus, coordination is a measure of the coordination of the system.

Port industry and economic growth belong to two systems. The development of port industry is affected by factors such as economic trade, shipbuilding industry and government's legal policy. Similarly, economic growth will be affected by the accumulation of capital, labor input, technological progress and other factors The coordination between the port industry and economic growth is to deal with the interrelationship between these two parameters in order to improve the overall output function of the two systems and to promote the continuous development of the world economy. And coordination is used to measure the relationship between the two indicators, is a quantitative measure of this relationship.

\subsection{Index System}

In order to be able to measure the degree of coordination between the two industries, considering to reflect, monitor, compare, evaluate and predict the principle of the analysis of the object, the paper analyzes the relationship between the port industry and the economic growth, Port industry development and economic growth indicators to select the index system, in order to reflect the development of China's port industry and economic growth of the respective characteristics of the characteristics and factors. Due to the large number of factors influencing the port industry and economic growth, and there is a great correlation between the different indicators, through the analysis of the index system, the indicators that have significant influence on the evaluation results are selected as the analysis of the port industry and economic growth Indicators of covariance measurement.

To select indicators [4] influencing the development of the port industry, respectively, from the port-related industries development level, maritime fleet, economic and trade, talent and technology, ports, government investment in six aspects to measure. As shown in Table 1.

As for indicators [5] selected affecting the economic growth.
Specifically, from the following seven aspects such as the accumulation of capital, resource consumption, economic development system, labor costs, science and technology education level, urbanization rate and degree of industrialization to make judgments.

\subsection{Coordination Model and Type}

The relationship between port industry and economic growth is a dynamic process. There may be a big gap between the two stages. However, there is a reasonable interval between the port industry and the economic growth. As long as the coordination of the two in the threshold range, not enough to affect the overall relationship between the two, this development model can be recognized, of course, the overall development of the two to maintain the optimal state is the best. For this idea, we define the formula for the degree of coordination:

$$
\begin{gathered}
C_{X Y}=1-\delta / \mu \\
\mu=\frac{X+Y}{2} \\
\delta=\sqrt{\frac{(X-\mu)^{2}+(Y-\mu)^{2}}{2}}
\end{gathered}
$$

In the above formula, $\mathrm{X}$ is the comprehensive index of the development of port industry in China, $\mathrm{Y}$ is the comprehensive index of China's economic growth, $\mathrm{C}_{\mathrm{XY}}$ is the coordination degree of port industry and economic growth, $C_{X Y} \in[0,1] . C_{X Y}$ is determined by the variables $X$ and $Y$, and when $X$ and $Y$ are both positive and the values are equal, $C_{X Y}$ takes the maximum value and the value is 1 . According to the value of $\mathrm{X}$ and $\mathrm{Y}$, the coordination degree of the two will change, and the degree of coordination will be divided into the following categories according to the value of $\mathrm{C}_{\mathrm{XY}}$.

\subsection{Calculation Method}

\subsubsection{Standardization of data}

Due to the existence of different dimensions of the original data for the different indicators in the system, and the size of the order of magnitude is not the same. Data for different indicators could not be compared and calculated directly. In order to eliminate the impact of these factors, evaluation index of different dimensions need to be transformed into dimensionless standardized indicators, through an appropriate way. That is, the standardization of indicators. Considering that the covariance matrix of each index data processed by the mean method can reflect the difference in the degree of variation of each index in the original data and the information of the degree of mutual influence of each index, this paper adopts the mean method to carry out the index standardized processing.

Let $\hat{x}_{i j}$ be the normalized value of the i-th-evaluation index at the $\mathrm{j}$-th time point, $\hat{\mathrm{x}}_{\mathrm{ij}}$ is the original value of the $\mathrm{i}$-th evaluation index at the jth time point, and $\mathrm{m}$ is the total length 
of the time series. Then

Standardization formula for port industry development indicators:

$$
\begin{array}{r}
\hat{x}_{i j}=\frac{x_{i j}}{\bar{x}_{i}} \\
\bar{x}_{i}=\frac{1}{m} \sum_{j=1}^{m} x_{i j}
\end{array}
$$

Among them, $\overline{\mathrm{x}}_{\mathrm{i}}$ is the average of the original indicators of the development of the port industry;

Standardization formula for economic growth indicators:

$$
\begin{array}{r}
\hat{y}_{i j}=\frac{y_{i j}}{\bar{y}_{i}} \\
\bar{y}_{i}=\frac{1}{m} \sum_{j=1}^{m} y_{i j}
\end{array}
$$

\begin{tabular}{|c|c|c|}
\hline Target layer & Criteria layer & Index layer \\
\hline \multirow{21}{*}{$\begin{array}{l}\text { The indicator system } \\
\text { that affects the } \\
\text { development of port } \\
\text { industry }\end{array}$} & \multirow{4}{*}{$\begin{array}{c}\text { Port - related industry } \\
\text { development level }\end{array}$} & Shipbuilding industry development level \\
\hline & & $\begin{array}{c}\text { Maritime trade service industry } \\
\text { development level }\end{array}$ \\
\hline & & Average return on capital of shipping enterprises \\
\hline & & Enterprise fleet market share \\
\hline & \multirow[t]{5}{*}{ Sea fleet } & China's maritime fleet capacity scale (100t dwt) \\
\hline & & $\begin{array}{l}\text { The proportion of domestic imports and exports } \\
\text { of goods transported by their own ships }\end{array}$ \\
\hline & & Fleet structure \\
\hline & & Fleet age structure \\
\hline & & Route density \\
\hline & \multirow[t]{3}{*}{ Economic and Trade } & $\begin{array}{c}\text { China's import and export } \\
\text { trade volume (ten thousand US dollars) }\end{array}$ \\
\hline & & Sea freight \\
\hline & & $\begin{array}{l}\text { The degree of development of } \\
\text { the financial industry }\end{array}$ \\
\hline & \multirow[t]{4}{*}{ Talent and Technology } & Sailing senior personnel training \\
\hline & & $\begin{array}{l}\text { Training of professional personnel } \\
\text { in shipping enterprises }\end{array}$ \\
\hline & & Maritime information service platform \\
\hline & & Maritime research investment \\
\hline & \multirow[t]{3}{*}{ Port } & The natural conditions of the port \\
\hline & & $\begin{array}{c}\text { Port throughput } \\
\text { Port infrastructure improvement }\end{array}$ \\
\hline & & Port logistics service level \\
\hline & \multirow[t]{2}{*}{ Government investment } & $\begin{array}{l}\text { The state of the domestic } \\
\text { shipping industry policy force }\end{array}$ \\
\hline & & $\begin{array}{l}\text { Government 's financial support for the } \\
\text { development of maritime industry }\end{array}$ \\
\hline
\end{tabular}

Among them, $\bar{y}_{i}$ is the average of the original indicators of economic growth;

Table 1. The indicator system of the effects in the port industry's development

\subsubsection{Relevance analysis for indexing}

The basic principle of correlation analysis is to calculate the correlation coefficient between the two evaluation indexes, and to remove the set of indexes with large correlation coefficient, so as to eliminate the influence of information repetition and simplify the index evaluation system [6].
Let $r_{i j}$ be the correlation coefficient between the $i$-th index and the $j$-th index, $Z_{k i}$ denote the value of the $k$-th time period of the $\mathrm{i}$-th index, $\bar{Z}_{\mathrm{i}}$ denote the expected value of the time series of the $i$-th index, and $n$ be the length of the time series.

According to the calculation of the correlation coefficient, then 


$$
\mathrm{r}_{\mathrm{ij}}=\frac{\sum_{\mathrm{k}=1}^{\mathrm{n}}\left(\mathrm{z}_{\mathrm{ki}}-\overline{\mathrm{Z}}_{\mathrm{i}}\right)\left(\mathrm{z}_{\mathrm{kj}}-\overline{\mathrm{z}}_{\mathrm{j}}\right)}{\sqrt{\sum_{\mathrm{k}=1}^{\mathrm{n}}\left(\mathrm{Z}_{\mathrm{ki}}-\overline{\mathrm{Z}}_{\mathrm{i}}\right)^{2}\left(\mathrm{z}_{\mathrm{kj}}-\overline{\mathrm{Z}}_{\mathrm{j}}\right)^{2}}}
$$

In order to be able to effectively select a representative evaluation index, we need to define the value of $r_{i j}$, specify the critical value $\mathrm{M}(0<\mathrm{M}<1)$, if $\left|\mathrm{r}_{\mathrm{ij}}\right|>M$, you can delete one of the two evaluation Index, leave another, if $\left|r_{i j}\right|<M$, that is to say there is little correlation between the two indicators , and both are retained.

Through the relevance of the index screening, the impact of repeated information on the evaluation can be effectively removed, and the evaluation of the index system being simplified.

Table 2. The indicator system of the effects in the economic growth

\begin{tabular}{|c|c|c|}
\hline Target layer & Criteria layer & Index layer \\
\hline \multirow{21}{*}{$\begin{array}{c}\text { The indicator system } \\
\text { that affects } \\
\text { economic growth }\end{array}$} & \multirow[t]{3}{*}{ Capital accumulation level } & GDP \\
\hline & & Foreign investment level \\
\hline & & Foreign exchange reserves \\
\hline & \multirow[t]{2}{*}{ Economic development system } & The proportion of public ownership economy \\
\hline & & $\begin{array}{l}\text { Taxation accounts for the proportion } \\
\text { of the national economy }\end{array}$ \\
\hline & \multirow[t]{3}{*}{ Labor input } & Employment rate \\
\hline & & Per capita income of urban residents \\
\hline & & Per capita income of rural residents \\
\hline & \multirow[t]{3}{*}{ Urbanization level } & Proportion of urban and rural population \\
\hline & & Urban land \\
\hline & & Urban population aggregation degree \\
\hline & \multirow{4}{*}{$\begin{array}{l}\text { Level of science and } \\
\text { technology education }\end{array}$} & Accept the number of higher education \\
\hline & & Per capita education level \\
\hline & & $\begin{array}{c}\text { Education and Research Funds Proportion of } \\
\text { National Economy }\end{array}$ \\
\hline & & Number of national patents \\
\hline & \multirow[t]{3}{*}{ Degree of industrialization } & Three types of industrial structure than \\
\hline & & Industry coordination degree \\
\hline & & High - tech industrialization rate \\
\hline & \multirow[t]{3}{*}{ Resource utilization } & Energy consumption elasticity coefficient \\
\hline & & Resource consumption \\
\hline & & Renewable energy utilization \\
\hline
\end{tabular}

\subsubsection{Calculation of Comprehensive Evaluation Index Affecting Port Industry Development and Economic Growth}

Because the factor influencing the development of the port industry and the economic growth is the comprehensive index composed of different indicators, it is a multi-index statistical analysis method. Therefore, this paper chooses the correlation-principal component analysis [7] to measure the indicators. The essence of the principal component analysis is the linear combination of the observed indicators. The calculation model of principal component analysis is:

$$
\begin{array}{r}
\mathrm{x}_{\mathrm{i}}=\alpha_{\mathrm{i} 1} \hat{\mathrm{x}}_{\mathrm{i} 1}+\alpha_{\mathrm{i} 2} \hat{\mathrm{x}}_{\mathrm{i} 2}+\cdots+\alpha_{\mathrm{in}} \hat{\mathrm{x}}_{\mathrm{in}} \\
\mathrm{X}=\sum \omega_{\mathrm{i}} \hat{\mathrm{x}}_{\mathrm{i}} \\
\mathrm{y}_{\mathrm{j}}=\beta_{\mathrm{j} 1} \hat{\mathrm{y}}_{\mathrm{j} 1}+\beta_{\mathrm{j} 2} \hat{\mathrm{y}}_{\mathrm{j} 2}+\cdots+\beta_{\mathrm{jn}} \hat{\mathrm{y}}_{\mathrm{j} n} \\
\mathrm{Y}=\sum v_{\mathrm{j}} \hat{\mathrm{y}}_{\mathrm{j}}
\end{array}
$$

In the formula, $x_{i}$ and $y_{j}$ are the sovereign factors after the standardization of port industry and economic growth, and $\omega_{i}$ and $v_{\mathrm{j}}$ are the contribution rates of the sovereign factor eigenvalues of port industry and economic growth. $\hat{\mathrm{x}}_{\mathrm{ij}}$ is the $\mathrm{j}$-th index of the $\mathrm{i}$-th sovereign factor which influence the port industry. $\hat{y}_{\mathrm{ji}}$ is the $\mathrm{i}$-th index of the $\mathrm{j}$-th sovereign factor which influence the economic growth. $\mathrm{X}$ and $\mathrm{Y}$ are the comprehensive indexes of port industry development and economic growth respectively, $\mathrm{n}$ is the number of indicators. The relevant steps [7] of the principal component analysis is, take the calculation method of $\mathrm{x}_{\mathrm{i}}$ as an example:

(1) Standardize the index data processing, unified dimension;

(2) Calculate the normalization of the index data after the correlation coefficient, obtain the results of correlation coefficient matrix $\mathrm{R}_{\mathrm{n} \times \mathrm{n}}$;

(3) Calculate the eigenvalues $\lambda_{i}(i=1,2 \ldots n)$ of the matrix $R_{n \times n}, \lambda_{i}$ represents the total variance of the data of the original index explained by the $\mathrm{i}$-th sovereign factor $\mathrm{x}_{\mathrm{i}}$;

(4) Determine the value of $\mathrm{k}$, make the utilization rate 
of information reaching $85 \%$ or more, $\mathrm{k}$ indicates the number of indicators that affect the sovereign factor after screening;

$$
\frac{\sum_{\mathrm{i}=1}^{\mathrm{k}} \lambda_{\mathrm{i}}}{\sum_{\mathrm{i}=1}^{\mathrm{n}} \lambda_{\mathrm{i}}} \geq 0.85
$$

5) The contribution rate $\omega_{i}$ of the eigenvalue of the sovereign factor $\mathrm{x}_{\mathrm{i}}$ is:

$$
\omega_{\mathrm{i}}=\frac{\lambda_{\mathrm{i}}}{\sum_{\mathrm{i}=2}^{\mathrm{n}} \lambda_{\mathrm{i}}}
$$

(6) The weight of the index $\alpha_{i j}$ is determined by the expert consultation method [8].

Through the correlation analysis and principal component analysis, we can eliminate some non-quantifiable and high correlation index with the known indicators, select the indicators that have higher impact on the evaluation object as the calculation factor of the coordination degree, so as to analyze The relationship between port industry development and economic growth.

\section{The Empirical Analysis and Evaluation of Coordination Degree between Port Industry and Economic Growth}

\subsection{Selection of Samples and Data Sources}

In view of the index system which affects China's economic growth and the development of China's port industry, this paper chooses the data from 1990 to 2014 as the time series to analyze the relationship between China's economic growth and port industry. The data for the indicators used for coordination are from the website of the National Bureau of Statistics of the People's Republic of China, the website of the Ministry of Transport, the China Yearbook of Transportation, and the website of the China Shipbuilding Industry Association.

\begin{tabular}{|c|c|c|c|}
\hline Coordination type & $C_{X Y}$ & $\begin{array}{c}\text { Port industry and } \\
\text { economic growth of the } \\
\text { comprehensive indicators } \\
\text { X, Y value } \\
\end{array}$ & Coordination characteristics \\
\hline Class I & $0.8 \leq C_{X Y} \leq 1$ & $X \geq 0, Y \geq 0$ & $\begin{array}{l}\text { Very coordinated, the port industry } \\
\text { and economic growth are optimized } \\
\text { development, the system was the best } \\
\text { state }\end{array}$ \\
\hline Class II & $0.6 \leq C_{X Y}<0.8$ & $X \geq 0, Y \geq 0$ & $\begin{array}{l}\text { Coordination, the development of } \\
\text { port industry and economic growth are } \\
\text { relatively high level, the overall system } \\
\text { to the good direction }\end{array}$ \\
\hline Class III & $0.5 \leq C_{X Y}<0.6$ & $X \geq 0, Y \geq 0$ & $\begin{array}{l}\text { Relatively coordinated, the port } \\
\text { industry development and economic } \\
\text { growth in one of the comprehensive } \\
\text { level higher than the other, but the } \\
\text { system as a whole is still relatively } \\
\text { coordinated }\end{array}$ \\
\hline Class IV & $0.4 \leq C_{X Y}<0.5$ & $X \geq 0, Y \geq 0$ & $\begin{array}{l}\text { Not coordinated, economic growth } \\
\text { and port industry, the level of } \\
\text { imbalance, the development of the } \\
\text { system instability }\end{array}$ \\
\hline Class V & $0.2 \leq C_{X Y}<0.4$ & $X \geq 0, Y \geq 0$ & $\begin{array}{l}\text { Uncoordinated, the development of } \\
\text { the port industry and the level of } \\
\text { economic growth are relatively low, and } \\
\text { the development of the two is very } \\
\text { uneven, the overall system of instability }\end{array}$ \\
\hline Class VI & $0 \leq C_{X Y}<0.2$ & $X \geq 0, Y \geq 0$ & $\begin{array}{l}\text { Very uncoordinated, port industry } \\
\text { and economic growth in the } \\
\text { development of a comprehensive level } \\
\text { are in a low state, the overall system } \\
\text { was in recession }\end{array}$ \\
\hline
\end{tabular}

Table 3. The classification of coordination degree between the port industry and economic growth 
Table 4. The coordination degree of the port industry's development and economy growth in China (1990-2014)

\begin{tabular}{|c|c|c|c|c|}
\hline Time & $\begin{array}{c}\text { Port Industry } \\
\text { Development Index }\end{array}$ & Economic growth index & $\begin{array}{c}\text { Coordination } \\
\text { degree }\end{array}$ & $\begin{array}{c}\text { Coordination } \\
\text { type }\end{array}$ \\
\hline 1990 & 0.2294 & 0.6786 & 0.3004 & Class V \\
\hline 1991 & 0.2294 & 0.6863 & 0.2945 & Class V \\
\hline 1992 & 0.2249 & 0.6489 & 0.3138 & Class V \\
\hline 1993 & 0.2306 & 0.6739 & 0.3069 & Class V \\
\hline 1994 & 0.2563 & 0.6745 & 0.3646 & Class V \\
\hline 1995 & 0.2618 & 0.7148 & 0.3439 & Class V \\
\hline 1996 & 0.2680 & 0.7246 & 0.3495 & Class V \\
\hline 1997 & 0.2900 & 0.7336 & 0.3871 & Class V \\
\hline 1998 & 0.3021 & 0.7273 & 0.4157 & Class IV \\
\hline 1999 & 0.3426 & 0.7201 & 0.4976 & Class IV \\
\hline 2000 & 0.4071 & 0.8109 & 0.5312 & ClassIII \\
\hline 2001 & 0.4548 & 0.8750 & 0.5531 & ClassIII \\
\hline 2002 & 0.5195 & 0.9557 & 0.5818 & ClassIII \\
\hline 2003 & 0.6198 & 1.0871 & 0.6128 & Class II \\
\hline 2004 & 0.7503 & 1.1281 & 0.7156 & Class II \\
\hline 2005 & 0.8860 & 1.0872 & 0.8558 & Class I \\
\hline 2006 & 1.0235 & 1.0595 & 0.9755 & Class I \\
\hline 2007 & 1.1761 & 1.1001 & 0.9528 & Class I \\
\hline 2008 & 1.3481 & 1.1056 & 0.8602 & Class I \\
\hline 2009 & 1.4005 & 1.1813 & 0.8799 & Class I \\
\hline 2010 & 1.7948 & 1.2881 & 0.7676 & Class II \\
\hline 2011 & 2.0476 & 1.3941 & 0.7315 & Class II \\
\hline 2012 & 1.9988 & 1.4209 & 0.7610 & Class II \\
\hline 2013 & 1.9695 & 1.4652 & 0.7923 & Class II \\
\hline 2014 & 1.9685 & 1.4838 & 0.8014 & Class I \\
\hline
\end{tabular}

Source: 《China Statistical Yearbook》, 《China Transportation Yearbook》and China Shipbuilding Industry Association website

Economic growth index

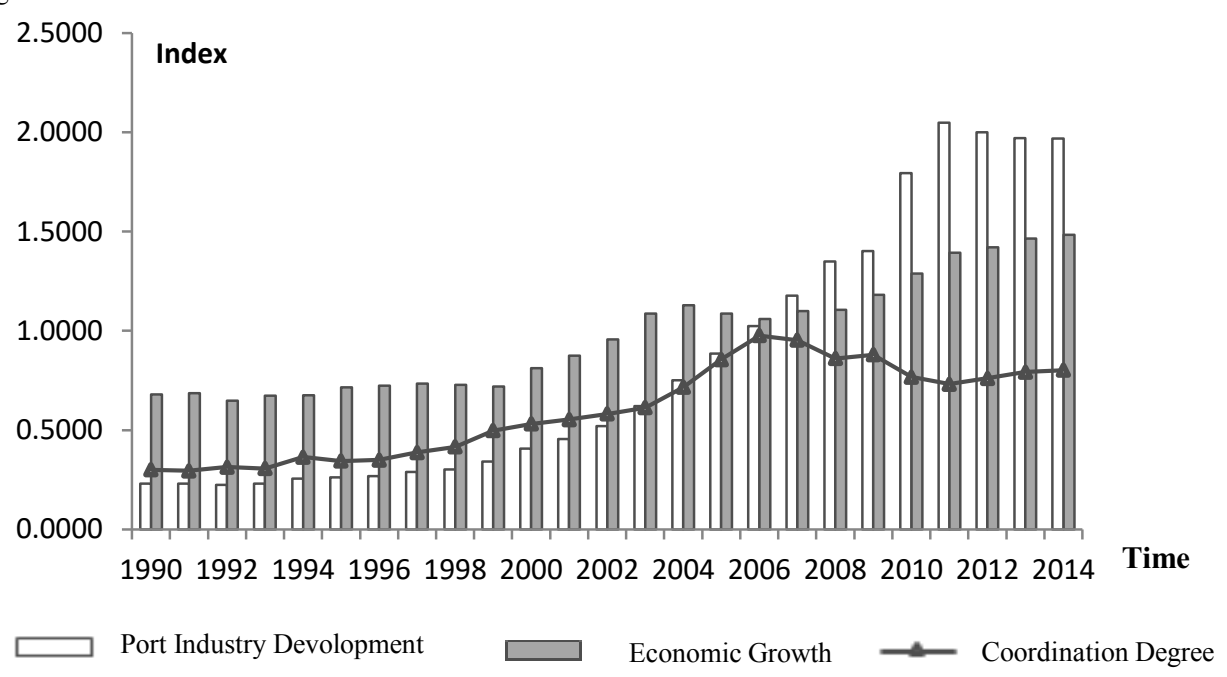

Fig 2. The changing curve of coordination degree between the port industry's development and economic growth in China 


\subsection{Analysis of Results}

After extracting the evaluation index by the correlation-principal component analysis, the index weight determined by the expert consultation method is brought into the calculation model of the coordination degree, and the coordination table between China's port industry and economic growth can be obtained. As shown in Table 4.

It can be seen from Table 4 and Figure 2, there have been six significant changes of the coordination of the relationship between China's port industry and economic growth. The first stage was in the early 1990s (1990-1991). Although China's reform and opening-up policy was effective, economic growth reached a certain scale, but because of the poor economic base in China, the structure of economic development is irrational and the economic growth is instability, resulting in a series of problems in China's economic growth, economic development, the level of comprehensive development in a low state. At the same time, the rapid development of economy and foreign trade brought by reform and opening-up policy has stimulated the huge demand for import and export goods for maritime transport. However, due to the limited ship capacity and relatively backward construction of port infrastructure, serious problem such as the pressure port phenomenon has been appeared in the development of the port industry.

The second stage is in 1992-1997, when China's port industry development and economic growth is in a state of incongruity. In 1992, Comrade Deng Xiaoping's "Southern Tour Speech" pointed out the direction of China's economic development. The upsurge of reform and opening up continued in our country. The foreign capital entered China's territory, and there was an investment boom in China. However, due to China's economic development system reform in the early stages, lacking effective policy guidance and macroeconomic regulation and control, which caused a lot of duplication of the project, a serious waste of resources, leading directly to China's economic growth reached a climax in 1992-1993, causing the phenomenon of overheating. Although economic growth maintained a high rate in this period, the economic development of the structural problems also highlighted. Therefore, the state in the 1993-1996 stage implemented the macro-control, which successfully controlled the momentum of economic growth and the level of economic growth has also been improved. Similarly, in this stage of development, the state has further expanded the scope of coastal openness, which greatly promoted the development of the coastal port industry. During that time, Ministry of Communications put fully effort to carry out the long-term planning of traffic infrastructure construction which named "three main one support" [9], made a series of planning and constructing achievements, not only in the supporting system, but the main water channel and the main port as well. At the same time, it brought the initial formation of the coal, oil, iron ore, grain-based bulk cargo terminals and container specialized terminals. However, due to the late development of China's port industry, infrastructure is still weak, so a short period of time the level of development will not be qualitative improvement, the overall level of development is still in a low state.

The third stage is in 1998-1999, when China's port industry and economic growth is in a state of less coordinated. During this period, China's economic growth rate is lower than the $9.5 \%$ growth rate since the reform and opening up. Economic growth failed to maintain the momentum of development, partly from the Southeast Asian financial turmoil in the second half of 1997. Although the financial turmoil did not have a direct impact on the Chinese mainland economy, coincided with Hong Kong and Macao return to the motherland, Hong Kong has been greatly affected as a financial center in Asia in the face of this financial turmoil. At the same time, Southeast Asia as an important area of China's foreign trade, China has also encountered some problems in foreign trade and foreign investment, which also led to some limits of the development of China's port industry at this stage.

The fourth stage is in 2000-2004, when China's port industry development and economic growth transformed from a relatively coordinated state to a coordinated state. From this stage we can see that China's port industry development system and economic growth are in the rising stage, and the development model is maturing, one of the important turning point is China's successful accession to the World Trade Organization in November 2001, which has produced a great impact on the Chinese economy growth. A significant change is that China's economic growth rate being substantial rebound. At the same time, with the formation of China's all-round, multi-level and wide-ranging pattern, China has made certain achievements in economy, politics, science and technology, culture and security. The relationship between China's economy and the world economy has been strengthened, and further reform of China 's economic system has also been accelerated. China has begun to play an increasingly important role in the world stage. However, in the early years of China's accession to the WTO, China was still in a passive and one-way state in relations with various WTO members [10], especially developed countries. Therefore, China has always been at the disadvantage in the foreign trade, which brought certain restrictions in implementing the strategy of "going out". As an important carrier of foreign trade, the port industry also ushered in a new era of development after China's accession to the WTO. As an important manufacturing country in the world, a large number of product that made in China began to enter international markets, which promote further innovation in China's port industry.

The fifth stage is from 2005 to 2009 , during which China's economic development as a whole showed a continuous wave of heat, China played an increasingly important role in international economic affairs. As the world's largest developing country, China's contribution rate to the world economy during this period of time reached $15 \%$, which has made great contributions to the development of the world economy. At the same time, China successfully held the 2008 Beijing Summer 
Olympics during this period, which not only shown the great achievements since China's reform and opening up to the world, but also enhance China's international status. The development of China's port industry has experienced a climax. China has grown as the world's maritime power. As 《2009 China's Shipping Development Report》 shows, which issued by the Ministry of Transport, the national port to complete the cargo throughput of 7.657 billion tons. In the top 10 ports of global cargo throughput, China has occupied eight seats and has become the world's largest country of port throughput. Therefore, at this stage, China's economic growth and the development of the port industry are in a period of rapid development of the golden period, the coordinated development of the relationship between the two are in good condition.

The sixth stage is from 2010 to 2014 , the development between port industry and economic growth is in a coordinated state. However, suffering the 2008-2009 US "subprime mortgage crisis", the world economy declined at this stage as a whole, which directly reflected by the substantial reduction in global trade demand. World's economic development is in trouble. Similarly, China's economic development in the face of this crisis has not escaped the tragedy of decline, China's economic growth rate has declined for five consecutive years. The reason for this can be divided into two kinds. One reason is that the volume of China's economic increased gradually, which reduced the pace of development. The other reason is that China's foreign trade development has been facing the challenge of global economic downturn. For this situation, China's government has introduced a series of policies to slow down the impact of the financial crisis on China, optimize the industrial structure, promote the supply side of the reform, China's economy also grew in a high speed in face of this crisis. As for port industry, after a boom of economic development in the last stage, China's port industry booming, has made unprecedented achievements, the comprehensive level of China's port industry development has reached a new height. But the resulting shortcomings of the airport empty ship is also fully exposed at this stage, the development of China's port industry experienced a cliff-style decline. However, the crisis also contributed to China's port industry, making it continue to develop in a more reasonable direction.

\section{Conclusion}

Based on the systematic review of the co-ordination model, this paper analyzes the various factors related to the growth of the port industry and economic and economic factors. By using the correlation analysis and the principal component analysis, the indicators are screened and the indicators with large correlation coefficients are removed, the impact of information duplication was also reduced, which makes the indicators strong representative, independent of each other. Through the quantitative measurement of the coordination degree, we can accurately identify constraints restricting the development of the port industry, in order to provide an important basis for formulating the strategy of the port industry developing in the future, and then guide the healthy development of the port industry.

The actual data calculation results show that there had been six significant changes in the relationship between the port industry and economic growth in China during the period from 1990 to 2014: (1) in the early 1990s (1990-1991), the rapid development of economic and foreign trade caused by the reform and opening up policy brought about a series of pressure ship pressure port phenomenon; (2) in 1992-1997, China's port industry development and economic growth were in a state of incongruity; (3) in 1998-1999, China's port industry and economic growth was in a state of less coordinated; (4) in 2000-2004, China's port industry development and economic growth were transforming from a coordinated state to a coordinated state; (5) in 2005-2009, the growth of China's economy and the development of the port industry were in a period of rapid development, and the coordinated development of the two was in a good state; (6) During the period from 2010 to 2014, the development of the port industry and economic growth is in a state of coordination. These changes are closely related to the background and policy environment of the time, in which the coordination degree of the two reached a high level in 2005-2009.

This work was supported by the major projects of the National Social Science Fund (13 \& ZD170), the New Century Excellent Talents Support Program of the Ministry of Education (NCET-13-0701) and the "Thirteen Five" Research Project of Dalian Maritime University (3132016361)

\section{References}

1. Zhangjingjing,Chenzhengjiang,Yangdegang. Construction and Application of Evaluation Model of Urban and Rural Coordination Degree [J]. Journal of Arid Land Resources and Environment,2007,21 (2) :85-94

2. Liming. Water transport on the contribution of China's national economy [D]. Dalian Maritime University master's degree thesis,2004

3. Zhangxiaodong,Chitianhe. Analysis on the Coordination of Regional Economy and Environment in China in the 1990s [J]. Geography Research,2001,20 (4):506-515

4. Sunyabo,Fanhouming,Liuyiying,Lizhenfu. Construction of Evaluation Index System of Shipping Power Based on Reliability and Validity Analysis [J]. Journal of Shanghai Maritime University, 2014,35(4):26-31

5. Wangjunlei,Wangzhaokai, Yangxiaoming. Economic Growth Quality Evaluation Model Based on Analytic Hierarchy Process [J]. Statistics and Decision, 2007

6. Chiguoqin,Caotingting,Zhangkun. Based on the correlation-principal component analysis of human 
comprehensive development evaluation index system construction [J].Systems Engineering Theory \& Practice,2012,32 (1) :111-119

7. Lihongxi. Research on Port Logistics Evaluation Based on Correlation - Principal Component Analysis [D]. Dalian University of Technology Master of Engineering degree thesis, 2013

8. Hanxiaohai,Zhangzhaihui,Sunfujun, Wangshaohua. Method of Determining Weight of Index Based on Principal Component Analysis [J]. Journal of Sichuan Ordnance,2012,33(10):124-126

9. Tongxinchun. On the Development and Changes of the Maritime Industry in New China [J]. Research on China 's Economic History,2012,2:127-137

10. Chentaifeng,Huangang. The Influence of China 's Entry into WTO on China: Post-evaluation based on international returns $[\mathrm{J}]$. National situation report,2009,12:1-34

11. Zhangxiaodong,Chitianhe. Analysis on the Coordination of Regional Economy and Environment in China in the 1990s [J]. Geography Research,2001,20 (4):506-515

12. Liuqiang, Chenyixian. A Summary of China 's Economic Growth since the 1990s [J]. Journal of Zhengzhou Institute of Aeronautical Industry Management, 2004,22 (1) :8-11

13. Panwenyan, Wangzongjun. Research on Evaluation Index System of Low Carbon Competitiveness
Based on Coordination Model [J]. Information magazine, 2012,31 (10):76-82

14. Liuyaobin, Songxuefeng. Analysis on the Coordination Degree between China 's Industrialization and Urbanization since the Reform and Opening - up [J]. Science and Technology Herald, 2005, 23 (2): 48-51

15. Zhangxiaodong, Zhudehai. Forecast and Analysis of China 's Regional Economy and Environment Coordination [J]. Resource science,2003, 25(2):1-6

16. Ministry of Communications,Ministry of Commerce. Provisions on the Administration of Foreign Investment in International Maritime Industry. (2004) Order 1

17. B Büttner. Effectiveness versus Efficiency: Growth Accelerating Policies in a Model of Growth without Scale Effect, German Economic Review, 2006, 7 (3), 297-316.

18. GLASS,A. and X.WU. "Intellectual Property Rights and Quality Improvement". Journal of Development Economics, 2007, 82: 393-415

19. Maddison A. Chinese economic performance in the long run[M].Organization for Economic, 1998

20. Jones, C.R\&D-based Models of Economic Growth[J].Journal of Political Economy,1995,6 (3) :286-297 